\title{
Interference: Its Role in the Target Language Mastery to Indonesian Learners
}

\author{
Win Listyaningrum Arifin \\ Universitas Negeri Yogyakarta \\ nurarifin_my@yahoo.com
}

\begin{abstract}
Interference form one language to target language is something that cannot be denied. This paper discusses about the notion of interference, interference and second or foreign language learning, interference and communication, interference and Indonesian learners and its process. In the interference, there are negative transfer that which leads to an error or inappropriate form in the target language and positive transfer that makes the learning easier. Furthermore, during the language communication, native language can influence target language and the like. Thus, interference in communication can be: (1) influence of language contact experienced by bilingual or multilingual person; (2) language infiltration that influence the system to both target and native language, causing negative effect; (3) personal utterances in a narrow space as a parole effect (speech). In addition, interference to Indonesian learners can be in the area of phonology, morphology, sentence, and semantics.
\end{abstract}

Keywords: Interference, Second or Foreign Language Learning, Indonesian Learner

\begin{abstract}
Abstrak
Tulisan ini bertujuan untuk menunjukan bagaimana percampuran bahasa petama seseorang, dalam hal ini lokal dan bahasa indonesia, pengaruh penguasaan bahasa asing terhadap pelajar bahasa indonesia. Mempengaruhi antar bahasa yang nampak dalam penggunaan kata-kata atau frase-frase bahasa lain menyatu dengan bahasa asli adalah hal yang normal. Percampuran bahasa disebabkan oleh penggunaan peraturan berbicara dari satu bahasa ketika berbicara yang lainnya. Percampuran bahasa adalah suatu masalah norma bahasa dalam percakapan sebagai akibat dari hubungan bahasa yang dilakukan oleh orang yang berdwibahasa atau banyak bahasa. Penggunaaan beberapa kata dan frasa yang tidak biasa, memerlukan sinonim, penggunaan bahasa asing yang bergengsi dan ketidakloyalan penutur bahasa
\end{abstract}


dengan dwi/multi bahasa tampak krusial yang disebabkan oleh percampuran bahasa. Ini mungkin didasari oleh fakta-fakta bahwa percampuran bahasa terdapat dalam fonologi, tata bahasa, penggabungan kata, rangkaian kata dan kalimat, percampuran bahasa memang langkah paling awal untuk penggabungan walaupun hal itu seperti proses penyambutan penggunaan bahasa ibu atau bahasa lain dalam penggunaan bahasa target. Penggabungan selalu diukur oleh kamus. Jika kata yang dihasilkan dari proses pencampuran bahasa tidak akan seperti fenomena percampuran bahasa tetapi penggabungan seolah-olah kata tersebut tertulis di kamus melalui sebuah proses peminjaman/borrowing dan semacamnya.

Kata Kunci: Percampuran Bahasa, Penggabungan, Pelajar Bahasa Indonesia, Komunikasi dan Penguasaan Bahasa Kedua dan Asing

\section{Introduction}

Language is always developed and changed. These phenomena occur when there are changes in social, economics, and cultures. Fast language development mostly happens on fields of science and technology. Influencing process between languages cannot be ignored as the language development is directly influenced by certain fields as economics, politics, cultures, sciences, and etc. Thus, language as part of integrative culture cannot be separated from factors that contribute to a change. Influencing between languages that appears in the using of words or phrases of other language internalized in native language is normal feature. Weinrich (in Chaer dan Agustina 1995:159) stated that language contact is an event of using two languages interchangeably done by a speaker. Later, transmission or language element transfer from one language to another language covers all levels. Consequently, borrowing and influencing to language elements from one language to another language cannot be ignored. Suwito (1985:39-40) stated that if two or more languages were used interchangeably by a speaker, language contact would appear. Surprisingly, interference will appear both in 
oral and written form. Krashen (1981) stated that interference is a negative transfer that consists of errors. The errors are not traceable to the structure of L1 and commonly practiced by L2 learners. The L1 role in L2 proficiency is as a substitute utterance initiator. Taken into consideration, bilingualism or even multilingualism background normally will cause interference and integration.

In reality this is not the case. Second language learners appear to accumulate structural entities of the target language but demonstrate difficulty in organising this knowledge into appropriate, coherent structures (Bhela, 1999). If the structures of the two languages are distinctly different, then one could expect a relatively high frequency of errors to occur in L2, thus indicating an interference of L1 on L2 (Dechert, 1983 and Ellis, 1997). The second language learning environment encompasses everything the language learner hears and sees in the new language. Regardless of the learning environment, the learner's goal is mastery of the target language. The learner begins the task of learning a second language from point zero (or close to it) and, through the steady accumulation of the mastered entities of the target language, eventually amasses them in quantities sufficient to constitute a particular level of proficiency (Dulay, Burt \& Krashen, 1982 and Ellis, 1984). This characterisation of language learning entails the successful mastery of steadily accumulating structural entities and organising this knowledge into coherent structures which lead to effective communication in the target language (Rutherford, 1987).

Alwasilah (1985:131) defined interference based on Hartman and Stonk formulae that interference is an error caused by a tendency of using certain language utterances to another language that cover pronunciation, structure, and vocabularies. Meanwhile, Jendra (1991:109) proposed many 
language aspects that contribute interference i.e. phonology, morphology, syntax, lexicon, and semantics (in Suwito,1985:55).

Dulay, et al (1982) define interference as the automatic transfer, due to habit, of the surface structure of the first language onto the surface of the target language. Lott (1983: 256) defines interference as 'errors in the learner's use of the foreign language that can be traced back to the mother tongue'. To Nababan (1984), interference takes place when usual utterances of mother language or dialect of certain language appear while a person is using other language. In line with Nababan, Chaer and Agustina (1995: 168) stated that interference is norm declination of one or more languages.

\section{Discussion}

\section{The notion of interference}

Extensive research has already been done in the area of native language interference on the target language. Dulay et al (1982) define interference as the automatic transfer, due to habit, of the surface structure of the first language onto the surface of the target language. Lott (1983: 256) defines interference as 'errors in the learner's use of the foreign language that can be traced back to the mother tongue'.

To get a clear picture of interference, the followings are foundation definition of interference according to sociolinguists. Chaer (1998:159) clarified that interference term was firstly introduced by Weinrich to state a systemized change of certain language as a condition after the mentioned language interacted to elements of other language done by bilingual person. Interference refers to entering elements of certain language outside the understanding of other language e.g. put clause or phrases of Indonesia while a person is speaking deliberately in English. 
Hayi (1985:8) referred to Valdman (1966) that interference is a burden experienced by non-native speaker of certain language who studied second or foreign language. Thus, transferring or moving negative elements of native language into the target language that after all distracted the second or foreign language mastery.

Another opinion promoted by Alwasilah (1985:131), he stated interference, as previously introduced by Hartman and Stonk as slipped system caused by the usual using of other language utterances cover pronunciation, structure and word themselves when a person is trying to master languages outside his native. Suhendra Yusuf (1994:67) stated that the major factor caused interference is the distinction of sources between languages in the structure and words formation. Take for an example, Indonesian learner of English cannot find any inflectional word in Indonesia while there are inflectional words in English (both English and Indonesian have derivational words/affixes). Thus, the learner will find difficulty in translating such inflectional affixes found in the sentences. 16 tenses of English will be very difficult to be translated if modifier of time was stated.

To add, Jendra (1995:187) stated that interference is deliberated infiltration of native to second or foreign language. Bilingualism that usually applied phonetic system of native language to another language will affect the target language. Thus, interference is a big change that is very dominant in the language development. English and Arabic which are famous with their vocabularies (after words are completed with affixes), interference cannot be separated from their development. Interference form one language to target language is something that cannot be denied. Hence, interference cannot also be put away from the speaker attitude and aptitude. Bawa (1981: 8) proposed three main characteristics of language attitude and aptitude; they are (1) language loyalty, loyalty to certain language, (2) language pride, a 
pride to certain language, and (3) awareness of the norm, awareness to language norms. Incomplete understanding of a language learner causes negative effect toward the existence of his own language. Thus, Bawa pointed it as the causing factor of interference. Viewing purity of language, interference in all levels (phonology, morphology, and syntax) is a destructive illness for language that must be put away (Chaer and Agustina, 1998: 165).

\section{Interference and its role to second or foreign language competence}

The notion of interference according to Richard, Platt, and Platt (1992) is a negative type (negative transfer) of language transfer. It is the use of a native-language pattern or role which leads to an error or inappropriate form in the target language. For example, a French learner of English may produce the incorrect sentence 'I am here since Monday' instead of 'I have been here since Monday' because of the transfer of French pattern that doesn't differentiate tenses patterns between Present Tense and Present perfect Tense. Thus, the modifier of time to judge which tenses to be used does not exist.

On the other hand, another language transfer is positive transfer that makes the learning easier, and may occur when both native language and the target language have similar form. Take foe an example, both English and French have the word 'table' which meaning is similar (to put books, to write down on it, etc.).

Interference is caused by the use of rules of speaking from one language when speaking another. English always greets "How are you?" while Malay uses "Have you eaten yet?" to greet. Evidence was shown by Krashen (1981) that was also compiled findings of other scholars. The research findings are: first, first language influence appears to be strongest in 
complex word order and in word for word translation. Kellerman ( 1978) in Krashen (1981) stated the existence of interference. The acquirers must perceive a similarity between items in the first and second or foreign language. Items that appear to be language specific (e.g. idioms) will be less prone to transfer. Acquirers often fall back on the first language when they have not acquired aspects of the target language.

Second, First language influence is weaker in bond morphology. Inflectional morphology belongs to the category of structure that performers generally do not transfer in second or foreign language performance. Inflectional morphology as bond morphology such as suffixes of -s, -ed, -ing; suffixes -er than, -est in degree of comparison; possessive; etc. And, Indonesian learners of English will not put similar inflectional to English as Indonesia learners only understand derivation.

Third, first language influence seems to be stronger in 'acquisition poor' environments. Interference occurs when natural appropriate intake is scarce and where translation exercises are frequent. E.g. sign of first language influence in immersion bilingual programs in schools in Indonesia where input is often primarily from teacher and not from peers.

Later, he drew a conclusion that first language interference may therefore be an indication of low acquisition. However, in the long run, it is much more useful when language is used for the purpose of communication.

There are many factors that contribute interference (Weinrich, 1970:64-65): first, speaker bilingualism background. Bilingualism is the major factor of interference as the speaker is influenced by both of the source and the target language. Indonesias student who is Javanese and is studying good Bahasa tends to put his Javanese language into Indonesia. Look the example, 'Andi, apakah kamu bisa mengerjakan soal matematika ini? Tanya guru, then Andi answered, 'Tidak bisa Bu guru, lha wong itu angel'. The 
impression of 'lha wong' is usual in Javanese cultural insight. The word 'angel' means difficult in Bahasa, the student should reply his teacher with “Tidak bisa Bu Guru, Soalnya sulit'. Regarding this condition, the student is a second grade of elementary school.

Second, disloyalty to target language. Disloyalty to target language will cause negative attitude. This will lead to disobedience to target language structure and further force the bilingualist to put uncontrolled structure of his first language elements to output in practicing words utterances both oral and written. Students whose language background of TL is limited tend to put words in sentences or oral in structure and sense of first language.

Third, the limited vocabularies of TL mastered by a learner. Vocabularies of certain language mostly are about words of surroundings connected to life. Thus, a learner who is willing to master another language will meet new words differ from his native words. In order to be able to speak as natives of TL, vocabularies take a big role. The more vocabularies someone has, the better he masters TL. Foreign language learner will try to put deliberately his native word to state some points when he cannot find the best words of TL.

Interference as the effect of new words entries is normally done by another language learner. A learner's new word entries from TL as the effect of interference will be easily internalized and integrated as those new words are received after the learner made mistake in delivering words of TL.

Fourth, needs of synonym. Synonym in language usage plays an important role as word chosen variation in order not to repeat similar word during the communication process (redundancy). Implementing synonym in a language contact will contribute to interference in the form of adoption and borrowing of new words from SL to TL. Thus, need of synonym for certain word from SL to TL is seemingly aimed to intensify meaning. 
Fifth, prestige and style. Applying unfamiliar words (foreign words) during a communication practice which dominant words are languages of both speaker and receiver is something else. Those unfamiliar words usage is aimed to get a pride. Interference will appear as there are certain words even though the receiver probably cannot catch the real idea of the speech. The usual unfamiliar words usage will become a style of the user. Unfortunately, the user sometimes does not understand the real meaning whether the meaning is denotative or connotative. The common feature is that many language users put derivational affix -ization in every word. To note, affix ization is an adopting and borrowing process from English to state nouns.

\section{Interference in communication}

Rajend Meshtire (2008) in Spolsky and Hult (2008) stated that the main focus in sociolinguistics falls on language use within a speech community. Sociolinguistics is generally characterized by close attention to the actual speech of representative sections of a community, rather than to somewhat static and idealized patterns one finds in formal writing. Thus, it adopts a non-prescriptive approach to its subject matter, avoiding subjective judgments about whether some aspects of language are better than another.

In a multilingual culture where several languages coexist in a society, sociolinguistics notes that these languages frequently influence each other. As a discipline that digs the study of linguistic variation, sociolinguistics focuses on the form of speakers' utterances rather than the content of communication itself.

As being stated earlier, interference is a problem of language norm in speech as an effect of language contact done by bilingual or multilingual person. Beside language contact as Weinrich statement (in Sukardi, 1999:4) the causing factors of interference are the limited words of certain language 
in facing global development. The unusual using of some words or phrases,, need of synonym, prestigious foreign language usage, and disloyalty of a speaker with bilingual or multilingual are seemingly crucial cause of interference.

Jendra (1991:105) pointed out that there are three main elements in interference i.e. donor language that infiltrated its elements and systems to another language, recipient language as language that receive other language elements and systems, and imported words from one language to another language. During the language communication, native language can influence target language and the like. Thus, interference in communication: (1) influence of language contact experienced by bilingual or multilingual person; (2) language infiltration that influence the system to both target and native language, causing negative effect; (3) personal utterances in a narrow space as a parole effect (speech).

Yusuf (1994:71) divided interference events into four types, i.e.: first, phonic interference. This occurs when a language user uses certain vocals or sounds (as dialects or accents) of his native in producing words of TL. An English learner from Sumbawa will be very difficult is sounding ' $V$ ' as being indicated in involvement, he will pronounce the word "inpolpement" unintentionally.

Second,grammatical interference. This feature takes place when an Indonesian English learner identifies morpheme or structure of his native into TL. Most of Indonesian will put Indonesian style of language when they make sentences. The sense is clearly appeared.

Third, lexical interference. This kind of interference takes place in varied forms, e.g. words and phrases and fourth, semantic interference. 


\section{Interference to Indonesian learners of second or foreign language}

As Indonesian English learner, I think that this is very important to view what most common problem is faced in mastering second or foreign language. Here are some detail information.

Interference in phonology

The example is a Javanese who is mentioning some places which words are initiated with letters $/ \mathrm{b} /, / \mathrm{d} /, / \mathrm{g} /$, and $/ \mathrm{j} /$, as Bandung, Deli, Gombong, and Jambi. He unintentionally will pronounce /mBandung/, /nDeli/,/nJambi/, and /nGgombong/ (Chaer and Agustina, 2004). Surprisingly, I myself feel funny when someone who is also a Javanese asks me my origin and my answer is 'I am from nJaweng' (while the correct is ' $\mathrm{I}$ am from Jaweng').

Interference in morphology

Morphological interference is regarded by many linguists as the most frequent one. It occurs in the word formation by absorbing other derivational affixes. We often hear Indonesian words kepukul, ketabrak, kebesaran, kekecilan, kemahalan, sungguhan, bubaran, duaan, etc., however the correct word formation should be terpukul, tertabrak, terlalu besar, terlalu kecil, terlalu mahal, kesungguhan, berpisah (bubar), and berdua (Chaer and Agustina, 2004). The previous data is clearly word formation process of morphological interference from root words that are added with certain affixes from indigenous language or other language (FL).

Interference in sentence

This interference is a rare phenomenon. In fact, interference in sentence should be ignored as sentence pattern is a main character of certain language. Pay attention to these two sentences, "Rumahnya ayahnya Ali yang besar sendiri di kampung itu", and "Makanan itu telah dimakan oleh saya". The sentence form is indirectly influenced by native language understanding 
of someone that causes grammatical interference as there are the best sentence formation for those sentences, i.e.: "Rumah ayah Ali yang paling besar di kampung ini", and "Makanan itu telah saya makan" (Chaer and Agustina, 2004). The language learner is trying to simplify the context by mixing sentence pattern between native language and target language.

\section{Semantic interference}

According to recipient language, semantic interference is occurs when the recipient language absorbs cultural insight of words as the origins from another language. This process is known as expansive. E.g. Indonesian takes words from Greece-Latin as demokrasi, politik, revolusi, and many more (Chaer and Agustina, 2004). Surprisingly, this borrowing process is natural and normal. English also takes many stems from other languages such as Latin for morpheme geo-, bio-, ology, -ghraphy, etc. The first process is through interference and then goes to integration by passing borrowing process.

\section{Integration process in Bahasa Indonesia}

Integration is viewed to be a distractor in bahasa Indonesia. Chaer (1994: 67) stated that integration is element of foreign language in which considered, treated, and used as a part of receptive language. Integration usually needs a long process as it must be suited to Bahasa Indonesia in terms of the pronunciation, the spelling, and even the grammatical/syntactical feature.

As a multicultural background country, Indonesia is enriched by its multilanguages feature of its people. Indonesia's inhabitants live in five big islands accross the country, they are Sumatera, Kalimantan, Jawa, Sulawesi, and Papua. Surprisingly, each big island is also divided into small islands. Each group of people has particular spoken language which is called 
indigenous languages as Javanese (mostly spoken in Java Island), Sundanese (spoken in West Javanese), Balinese (Balinese language), Sasak (Lombok or West Nusa Tenggara), Palopo (South Sulawesi), and hundreds of other languages. Thus, Bahasa Indonesia appeared to be national language to accommodate hundreds of local languages spoken and loved by the people. Bahasa Indonesia is usually used in formal occassion while local languages are used mostly in daily conversation. Automatically, local languages influence the using of Bahasa Indonesia in integration process. For example, the word "kurang" is originally derived from Javanese and Malay language. There are many others examples of local words internalized as Bahasa Indonesia (most are found in the dictionary of bahasa Indonesia).

Life is changing, thus it insists the global inhabitants change also not only the attitude but also the language using. Internationally, English is mostly spoken. Thus, English also influences Bahasa Indonesia as the impact of modernization through the process of integration. Unfortunately, people tend to use integrated language as it is comfortable to use. This is in accordance to the assumption of the need of prestige and style. It, then, contributes to the misusing of proper and correct of Bahasa Indonesia.

\section{Interference versus integration}

Interference differs from integration whereas integration puts other language elements in native language and further is regarded as part of the native language after treated to be in line systematically with the native pattern and structure (Jendra 1991:115). Suwito (1983:54), added that interference is speech parole only experienced by bilingual person and is rewarded as a language mistake. Interference is the biggest, the most important, and the most dominant problem in language change that needs a depth attention (Hockett in Suwito, 1983:54). This may be based on the facts 
that interference may appear in phonology, grammatical, word formation, word and sentence sequence, etc.

Integration is the using of another language elements systematically and seen as part of the speaker language done unconsciously (Kridalaksana: 1993:84). One form of integration is borrowing, adopting words from other language internalized into the native language. Some linguists stated that integration is very hard to be distinguished from interference. Chaer and Agustina (2004) referred to Mackey, that integration is obviously the product of interference.

Weinrich (1970:11) noted that a frequent using of certain words through interference will be accepted as part of language system of another language. Thus, integration happens. In other word, interference focuses on the process of administering words and integration is acquired and admitted words from another language. Integration is always measured by a dictionary. If words produced from interference process will be no longer as interference phenomenon but integration as if the words are written in dictionary. Again, words are beneficial to make deal. Integration should also be internalized the words in line with the grammatical structure of the natives. The process how a word is formed is not simple. Surprisingly, the integration process will be fast if only both languages have similarities. There are three timing considerations should be taken into account, (1) the difference and the similarity of the system language between the two languages. Do you find the answer?, (2) whether the language elements are needed or a compliment, and (3) language attitudes of a foreign language?

Instead of the difference between interference and integration, they are alike. They present as language effect after language contact is done. Both interference and integration occur in four language elements, i.e. phonology, grammatical structure, morphology, and semantics. On the other 
hand, interference must be distinguished from code switching and code mixing. Code switching to Chaer and Agustina (2004) is done due to several conditions and conducted intentionally. Meanwhile, code mixing is mixing elements of two different languages interchangeably is a consistent manner. Interference as one of topics studied in Sociolinguistics is aimed to know the ability of a speaker with two or more languages. Generally, interference takes place in the using of second or foreign language where the native language distracts the TL.

\section{Conclusion}

Interference is obviously known as an incomplete process of profi ciency of target language. The most common feature needed to be highly understood that target language mastery relates to developmental stage of a dynamic process. There are many factors that contribute to the TL mastery. The input for TL received by the learners should be in a correct manner. The learners' readiness to achieve foreign language, and best instruction to guide the pupils are also crucial factors that influence the learners' competence. If the factors do not work, problem of FL performance will appear. To conclude, I will take Ellis definition on interference. Ellis (1997: 51) refers to interference as 'transfer', which he says is 'the influence that the learner's L1 exerts over the acquisition of an L2'. He argues that transfer is governed by learners' perceptions about what is transferable and by their stage of development in L2 learning. He says that errors reflect gaps in the learner's knowledge; they occur because the learner does not know what is correct. Mistakes reflect occasional lapses in performance; they occur because, in a particular instance, the learner is unable to perform what he or she knows. 
Regarding experts perspectives on interference, I try to quote Puspa Ruriana et.al. conclusion (-) on interference that: (1) language contact causes interference for bilingual person, (2) interference is an insert system consciously from L1 to L2 (even from L2 to L1) that may cause negative impact for TL proficiency, and (3) interference is a personal speech which is narrow as a feature of parole (speech). On the other hand, integration is an advanced process of interference. Words of interference are no longer strange as the words are received, widely used, and even borrowed and then practiced and legalized as parts of a language.

Despite the difference between interference and integration, both of them have similar face in which they appear as a certain feature of language contact. To sum, they can obviously occur in phonology, grammatical feature, morphology, and semantics. Newmark (1966) suggested that the cure for interference is simply the cure of ignorance:learning. Interference can be limited or eliminated by natural intake and language use for the purpose of communication. Again, the natural-like acquistion of L2 proficiency will be highly achieved by learning.

\section{References}

Alwasilah, A Chaedar. 1985. Sosiologi Bahasa. Bandung: Angkasa

Bawa, I Wayan. 1981. Pemakaian Bahasa Indonesia yang Baik dan Benar. Denpasar: Jurusan Bahasa dan Sastra Indonesia Fakultas Sastra Universitas Udayana.

Bhela, Baljit. 1999. Native language interference in learning a second language: Exploratory case studies of native language interference with target language usage. International Education Journal Vol 1, No 1, 1999 
Chaer, Abdul \& Leonie Agustina. 2004. Sosiolingistik: Perkenalan Awal. Jakarta: Rineka Cipta

Chaer, Abdul. 1994. Linguistik Umum. Jakarta; Rineka Cipta.

Dechert, H.W. 1983. 'How a story is done in a second language' in C. Faerch and G. Kasper.eds. Strategies in Interlanguage Communication. London: Longman.

Dulay, H., Burt, M. \& Krashen, S. 1982. Language Two. New York: Oxford University Press

Ellis, R. 1997. Second Language Acquisition. Oxford: Oxford University Press

Hartmann, R.R.K \& F.C. Stonk. 1972. Dictionary of Language and Linguistics. London: Applied Science Publisher, Ltd.

Hayi, Abdul et. al. 1985. Interferensi Gramatika Bahasa Indonesia dalam Bahasa Jawa. Jakarta: Pusat Pembinaan dan Pengembangan Bahasa.

Hockett, Charles F. 1958. A Course in Modern Linguistics. New York: MacMillan Publishing Co Inc.

Jendra. I Wayan. 1991. Dasar-Dasar Sosiolinguistik. Denpasar: Ikayana.

Kridalaksana, Harimurti.1998. Introduction to Word Formation and Word Classes. Jakarta: Universitas Indonesia.

Krashen, Stephen D. 1981. Second Language Acquistion and Second Language Learning. Pergamon Press Inc.

Lott, D.1983. Analysing and counteracting interference errors. ELT Journal, vol.37/3, pp 256- 261.

Mackey, W.P. 1970. The Description of Bilingualism. publisher: -

Nababan, P.W.J. 1984. Sosiolinguistik. Jakarta: Gramedia

Newmark, L. 1966. "How not to interfere with language learning". Language Learning: The Individual and the Process. International Journal of American Linguistics 40: 77-78.

Ruriana, Puspa et.al. - .Interferensi dan Integrasi. Jakarta: Pusat Bahasa AlAzhar.

Rajend Meshtire. 2008. Sociolinguistics and Sociology of Language. In Spolsky, Bernard and Francis M. Hult. 2008. The Handbook of Educational Linguistics. Singapore: Blackwell Publishing. 
Richard, Jack C. John Platt and Heidi Platt. 1992. Longman Dictionary of Language Teaching and Applied Linguistics. England: Longman.

Rutherford, W.E. 1987. Second Language Grammar: Learning and Teaching, London: Longman.

Suwito. 1983. Sosiolinguistk: teori dan Problema. Surakarta: Kenary Offset.

Wardraugh, R. 1972. Introduction to Linguistics. New York: McGraw Hill Books Company.

Weinrich, Uriel. 1968. Language in Contact. Mouton: The Hauge-Paris 